\title{
EFFECT OF LOCAL SEA CUCUMBER METHANOL EXTRACT (Phyllophorus sp.) AS NATURAL ANTIFOULING AGAINST MACROFOULER (Nerita $\mathrm{sp}$ ).
}

\author{
Himatul Hasanah, Rizqi Abdi Perdanawati, Dian Sari Maisaroh
}

Marine Science Department, UIN Sunan Ampel Surabaya

E-mail: hhima.hs20@gmail.com

\begin{abstract}
Macrofouling is the activity of attaching biota with size $>0.5 \mathrm{~cm}$, which attach to and form a colony in the mariculture construction. The development of antifouling materials currently uses a lot of natural ingredients including marine life, namely sea cucumbers. This study aims to determine the activity of local sea cucumber (Phyllophorus sp.) Methanol extract as a natural antifouling against macrofouler Nerita sp. The experimental design for this study used a completely randomized design with five types of treatment, namely negative control treatment, extract concentration of 75 $\mathrm{mg} / \mathrm{ml}$, extracts concentration of $100 \mathrm{mg} / \mathrm{ml}$, extracts concentration of $200 \mathrm{mg} / \mathrm{ml}$ and positive control with three repetitions for each treatment. The results showed that the local sea cucumber (Phyllophorus sp.) methanol extract contained saponins, alkaloids, tannins, steroids and phenolic bioactive compounds. The local sea cucumber (Phyllophorus sp.) methanol extract has an effect on the antifouling rate value. The same thing also happened where the increasing concentration of local sea cucumber (Phyllophorus sp.) methanol extract gave a significant decrease in the regaining ability of macrofouler Nerita sp. Lethal concentration ( $\mathrm{LC}_{50}$ ) values of local sea cucumber methanol extract (Phyllophorus sp.) on macrofouler Nerita sp. were investigated. While the lethal concentration $\left(\mathrm{LC}_{50}\right)$ value of the lethal dose was estimated at $185.18 \mathrm{mg} / \mathrm{ml}$. This study shows that local sea cucumber (Phyllophorus sp.) has potential as an antifouling agent.
\end{abstract}

Keywords: local sea cucumber (Phyllophorus sp.), antifouling, macrofouler, Nerita sp.

\section{INTRODUCTION}

The existence of macrofouling becomes one of the serious problems caused by the risk of losses it causes. Macrofouling is the activity of attaching biota that has a size of $>0.5 \mathrm{~cm}$ which lives on and forms a colony [1]; [2]. Macrofouling has the ability to grow and develop rapidly in various constructions submerged by water. Accumulation process macrofouling that occurs sustainable development could raises problems both economically and operations [3]. Macrofouling consists of various groups include algae, mollusks, crustaceans, bryozoa and polychaeta. One type macrofouling that is thought most often found in coastal waters in jember area the mollusks, Nerita sp.

Nerita sp. is a type of mollusk gastropods that have a habit of life clings to rocky beaches as well as Breakwater. They include animals that soft-bodied and covered with a shell [4]. Nerita sp. can be herbivorous, carnivorous, omnivorous or detrivores [5].The existence of mollusks such as Nerita sp. allegedly resulting in impacts and losses for the environment. One of the impacts is its existence on a cultivation raft which causes the raft to sink [6]; [7]. In addition, the attachment of these biota too cause the occurrence damage to the floating bag net and an effect on decreasing seaweed production [8]. The presence of molluscs could causing net closure in aquaculture so as to increase the mortality of cultured fish and result in the spread of disease [9]; [10]; [11]; [12]. Embedding an organism on metal materials can intensively corrosion [13]. Damage to wood in coastal structures or ships occurs due to the attack of the attaching biota which causes surface changes [14]; [15]. Repair efforts because the damage was caused existence macrofouling requires a large amount of money as explained by [16] which states that the government and industry in America spent at least 200 million dollars to solve the problem. The damage brought about by existence macrofouling provide serious losses so that prevention efforts are needed. Prevention macrofouling usually done using antifouling paint.

Paint antifouling this prevent the occurrence macrofouling by creating an effective and constant biocide [7]. In general antifouling paint containing copper and TBT (tri-n-butyltin) as the active and most effective elements [7]. The existence of the active ingredients contained in the anti-fouling paint creates new problems because TBT is not only toxic to fouling organisms but also harmful to non-target organisms. In addition, TBT was also reported to be very bad poisonous and persistent in marine environment [17]; [18]. This is a new challenge for industry and government in developing alternative technologies to prevent pollution in construction and installation mariculture. Based on This problem requires an alternative compound that is environmentally friendly so that it does not cause disturbance and damage to nontarget organisms or the marine environment. One of the alternative compounds that can be used is extracts from 
marine life. Lately, many people use natural products as antifouling agents wrong only one with utilize marine life. a marine biota that can produce compounds antifouling $\mathrm{s}$ sea cucumber extract. Sea cucumber extract contains secondary metabolites such as alkaloids, steroids, sapogenin, saponins, triterpenoids, glycosaminoglycan, lectins, phenols and flavonoids [19];[20]. Based on the content of bioactive compounds it has, Holothuria can be used as antibacterial, antimicrobial, antifouling, anticancer, anti-tumor and immunostimulant [20]; [21].

Based on the facts that have been described, it is necessary to carry out further research regarding the effect of adding local sea cucumber methanol extract (Phyllophorus sp.) as antifouling an alternative to TBT compounds to make it more environmentally friendly. Laboratory tests are carried out to determine whether sea cucumber extract has the ability and potential as antifouling, so this research aims to find out whether addition extract methanol Local sea cucumbers can affect biota fouling.

\section{RESEARCH METHOD}

This research was conducted from January to July 2020. The materials used in this research are local sea cucumbers (Phyllophorus sp.) obtained from Kenjeran Beach, Surabaya. The test biota used is macrofouler Nerita sp. obtained from Pancer Beach, Jember.

This study used laboratory experimental methods. Collection Laboratory scale data is carried out by observing activities antifouling rate, regaining rate and lethal concentration 50. The experimental design for this study used a completely randomized design (CRD) with five types of treatment, namely negative control treatment, extract concentration of $75 \mathrm{mg} / \mathrm{ml}$, extract concentration of $100 \mathrm{mg} / \mathrm{ml}$, extract concentration of $200 \mathrm{mg} / \mathrm{ml}$ and positive control with three repetitions for each treatment.

\section{Samples collection}

Local sea cucumber samples (Phyllophorus sp.), obtained from sea cucumber fishermen at Kenjeran Beach, Surabaya (Fig. 1). The sea cucumber samples were stored in cooler box and given ice cubes with the aim of maintaining the freshness of sea cucumbers. Then the sea cucumber samples are taken to the laboratory for the extraction and identification process.

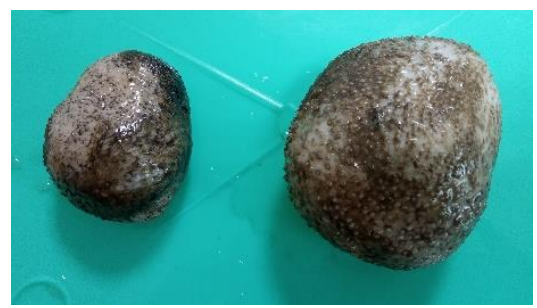

Fig. 1 Sample of local sea cucumber (Phyllophorus sp.)

The test biota used in this study is macrofouler that is Nerita sp . Nerita sp. used has a weight 0.65 gram. Operculum brownish in color, chalky like a thick plate, has hooks and a grained outer surface. Black shell with spots brownish. Nerita sp. is a group herbivorous animal. The test biota was obtained from coral and break water at Pancer Puger Beach, Jember (Fig. 2).

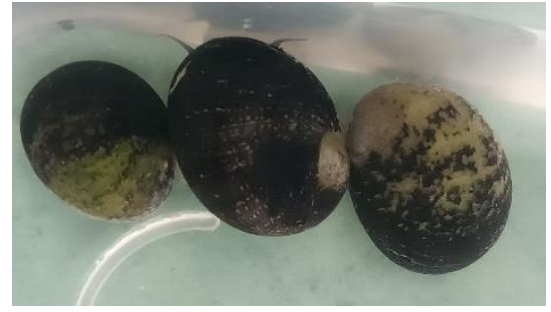

Fig. 2 Nerita $\mathrm{sp}$.

\section{Aclimatization Process}

The acclimatization process is an effort to adjust the physiological or adaptation of an organism to a new environment that it will enter [22]. After 3 days of aclimatization, the local sea cucumber were used for the antifouling test.

\section{Extraction method}

The extraction method in this study used maceration (immersion) with use solvent polar [23]. The polar solvent used in this study is a methanol solvent. Sample sea cucumber cleaned with Secrete all over stomach sea cucumber then washed with water flows. Cut sea cucumber small with purpose to enlarge the contact surface area with ingredient. sea cucumber Soaked in methanol solvent at room temperature with a ratio of mass and volume of extract making 1: 4 means that 1 gram of sea cucumber in $4 \mathrm{ml}$ of methanol solvent (Fig. 3).

Maserat stored in a container closed and not exposed to light. The maserate is then filtered, the filtrate is separated and the pulp is soaked back into the new solvent. The maceration process is carried out up to obtained a clear filtrate, which means that the solution is saturated. The filtrate obtained is concentrated through a simple distillation process. The result obtained is a paste later made three sorts concentrations with distilled water were $75 \mathrm{mg} / \mathrm{ml}, 100 \mathrm{mg} / \mathrm{ml}$ and $200 \mathrm{mg} / \mathrm{ml}$.

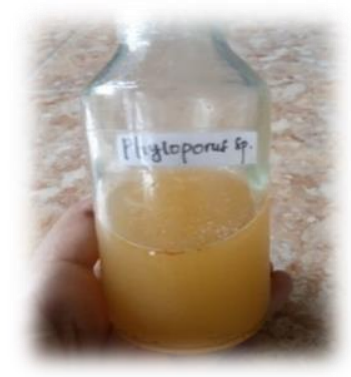

Fig. 3 Local sea cucumber methanol extract

\section{Bioactive Compound Test}

The extraction results obtained were analyzed qualitatively to determine womb compound bioactive in sea cucumbers. Qualitative analysis using phytochemical screening as follows:

\section{Alkaloid Test method Culvenor-Fitzgerald}

A sample of $1 \mathrm{ml}$ is mixed with $1 \mathrm{ml}$ of chloroform and $1 \mathrm{ml}$ of ammonia is put into a test tube then heated over a water bath, shaken and then filtered. The filtrate obtained is divided into three equal parts and then put into the tube each filtrate was taken and tested using mayer, wagner and dragendorf reagents. The 
formation orange, brown, and white deposits on each test indicating the presence of alkaloids [24].

\section{Flavonoid Test}

A sample of $1 \mathrm{ml}$ was mixed with $70 \%$ ethanol and then shaken and heated, shaken again then filtered. The filtrate obtained then $\mathrm{Mg} 0.1 \mathrm{~g}$ and 2 drops of concentrated HCI are added. The presence of flavonoids is characterized by their formation the red color on the ethanol layer.

\section{Saponin Test}

Saponin test is carried out by means of a sample of $1 \mathrm{ml}$ boiled in $10 \mathrm{ml}$ of water in a water bath. The filtrate was shaken and let stand for 15 minutes. Existence compound saponins indicated by the formation stable foam.

\section{Steroid Test}

A sample of $1 \mathrm{ml}$ was mixed with $3 \mathrm{ml}$ of $70 \%$ ethanol and added $2 \mathrm{ml}$ of $\mathrm{H} 2 \mathrm{SO} 4$ concentrated and $2 \mathrm{ml}$ anhydrous acetic acid (reagent Libermann-burchard). The presence of steroids is indicated by a color change from purple to blue / green.

\section{Triterpenoid}

Test compound triterpenoids done with add $1 \mathrm{ml}$ of sample to $2 \mathrm{ml}$ of chloroform and $3 \mathrm{ml}$ of acid sulfate concentrated. Existence triterpenoid compounds are characterized with formation color red brownish between surface.

\section{Phenolic Test}

Sample as much $1 \mathrm{ml}$ put into the test tube then add $1 \mathrm{ml}$ of $1 \% \mathrm{NaCI}$ solution and $1 \mathrm{ml}$ of solution gelatin $10 \%$. The formation of color deposits outih showing existence phenolic compounds.

\section{Tannin Test}

A sample of $1 \mathrm{ml}$ is boiled in $20 \mathrm{ml}$ of water over a water bath after which it is filtered. Filtrate that obtained add 2-3 drops of $1 \% \mathrm{FeCI} 3$. The presence of tannin compounds is indicated by formation color greenish brown or blackish blue.

\section{Water Quality Measurement}

Based on [18] growth influenced by the presence of abiotic components which include the physical properties of seawater such as salinity, brightness, $\mathrm{pH}$, temperature, tides and currents. Water quality parameters measured in this study include salinity, temperature, $\mathrm{pH}$ and DO.

\section{Antifouling Test}

Method that used in this research is an antisticking method. This method was chosen because it is considered to be faster in obtaining results. The antifouling test process begins with preparing a $500 \mathrm{ml}$ aquarium containing sea water containing local sea cucumber methanol extract (Phyllophorus sp.). Nerita sp. which has acclimatized transferred to a different aquarium. total Nerita sp. that used is 10 fish for each aquarium. The test was carried out with three replications for each treatment. Observation Nerita sp. carried out every $1 \times 24$ hours and $2 \times 24$ hours after exposure. The analysis used in this

study includes anti-adhesion analysis, regaining rate and analysis lethal concentration 50 or $\mathrm{LC}_{50}$.

This study used a factorial completely randomized design method.

A factorial completely randomized design is a design with two or more factors in an environment that is considered homogeneous [25]. The factor used in the study was the concentration of sea cucumber extract which was thought to contain antifouling compounds. The concentration factor of sea cucumber extract has three levels, namely $75 \mathrm{mg} / \mathrm{ml}, 100 \mathrm{mg} / \mathrm{ml}, 200 \mathrm{mg} / \mathrm{ml}$ concentration factor extract sea cucumber presumed effect on the observed response, namely the number of attached biota, regaining rate. The hypothesis is tested with using the Anova test using software SPSS.

Score $\mathrm{LC}_{50}$ obtained with use probit method so that obtained a linear regression equation $y=a+b x$. Price y stated that $50 \%$ of the test biota died for $2 \times 24$ hours. The value of $a$ and $b$ values are the slope and intercept values of the three concentrations used. The value of $x$ obtained is the concentration solution that cause mortality in the test biota by $50 \%$

$$
\mathrm{Y}=\mathrm{ax}+\mathrm{b}
$$

Price y stated that $50 \%$ of the test biota died for 48 hours. The value of $\mathrm{a}$ and $\mathrm{b}$ values are the slope and intercept values of the three concentrations used. The value of $\mathrm{x}$ obtained is the concentration solution that cause mortality in the test biota by $50 \%$.

\section{RESULT AND DISCUSSION}

\section{Phytochemical test of local sea cucumber methanol extract (Phyllophorus sp.)}

The phytochemical test is a qualitative test for the content of bioactive compounds (secondary metabolites) contained in the sample. The bioactive compounds tested include alkaloids, flavonoids, saponins, triterpenoids, steroids, phenolics and tannins. This is done aim at to knowing further benefits of the bioactive compounds produced. Extract analysis results local sea cucumber methanol ( Phyllophorus sp.) are presented in Table 1. Based on the table, it is known that methanol extractlocal sea cucumber ( Phyllophorus sp.) are known to have compound metabolites secondary including alkaloids, phenolics, steroids, saponins and tannins.

Table 1 The result of phytochemical content screening of Phyllophorus sp.

\begin{tabular}{|l|c|}
\hline \multicolumn{1}{|c|}{ Target } & The Result \\
\hline Alkaloid & + \\
\hline Phenolic & + \\
\hline Steroid & $\begin{array}{c}\text { A presence of brownish } \\
\text { red }\end{array}$ \\
\hline $\begin{array}{l}\text { Triterpenoid } \\
\text { colour }\end{array}$ \\
\hline Flavonoid & $\begin{array}{c}\text { A formation of reddish } \\
+\end{array}$ \\
\hline Saponin & + \\
\hline Tannin & \multicolumn{2}{|c|}{+ indicates the presence of the subtance) }
\end{tabular}


Positive reaction from the alkaloid test if the solution is formed an orange precipitate, a brown precipitate and sediment white after added reagent mayers, wagner and dragendorrf. Alkaloids are compounds organic which is basic and has quite a lot of hydrogen atomic groups. The hydrogen atom group in alkaloids can cause anesthetic effects and even death in animals depending on the dose given [3]. Alkaloid compounds produced by ascidians can reduce biofouling growth especially barnacles [26]. Alkaloids have the ability to be antibacterial because they can inhibit them process formation peptidoglycan in bacterial cells so that the cell wall layer is not formed completely, causing cell death [27]; [28].

Test phenolic done with adding $10 \% \mathrm{NaCI}$ and $1 \%$ gelatin solution. The presence of phenolic compounds is indicated by the formation of a white precipitate. Phenolic compounds are compounds with a high acidity when compared to alcohol. Phenol can cause chemical burning on the skin, the high level of phenol acidity can cause death in biofouling [3]. The phenol group has the ability to damage cell membranes, activate enzymes as well denaturate protein that cause cell wall damage due to subsidence ability permeability. Changes in cytoplasmic permeability can disrupt the transport of important organic ionions into cells so that they can inhibit growth and cell death [29].

Results of identification steroid compounds using reagents Libermanburchard in local sea cucumber methanol extract (Phyllophorus sp.) showed positive results. A positive reaction to the steroid test is a color change from purple to blue or green. Steroids are triterpenoid class compounds and are usually used as the basis for making drugs. Extracts containing steroid compounds have potential as antibacterial and anti-fungal [30]. Steroids have the ability to inhibit bacterial growth by damaging the bacterial cell membrane. This is also explained by [31] which states that the mechanism of steroids as antibacterial is closely related to membrane lipids and sensitivity to components steroids that cause leaks in the liposomes. Steroids can interact with cell membrane phospholipids which are permeable to lipophilic compounds so that could cause drop integrity membrane and changes in cell membrane morphology causing cells to become brittle and lysis [32].

Tannin compounds identified in local sea cucumber methanol extract (Phyllophorus sp.). The positive reaction of tannin compounds after adding $\mathrm{FeCI}_{3}$ $1 \%$ is formed a brown color. Tannins are a compound polyphenols that form insoluble complex compounds with protein. Tannins have ability to inhibit the activity of several digestive enzymes such as triptin, chymotrypsin amylase, and lipase besides that it can also inhibit iron absorption [33]. Tannins have ability inhibits bacterial growth by using the peptidoglycan synthesis process which results in the formation of imperfect cells. Cell wall shrinks and permeability disturbed so that inhibits bacterial growth [23]. Based on the statement of [3] tannin compounds have an $\mathrm{OH}$ group which functions to reduce the oxidation and reduction reaction processes so that they have the ability to inhibit the release of $\mathrm{Fe}+2$ ions as a cause of corrosion and the attachment of fouling biota to the surface layer of the iron plate.
Saponins are produced as a form of chemical selfdefense for sea cucumbers in nature. Saponins are also believed to have biological effects including anti-fungal, cytotoxic against tumor cells, hemolysis, immunostimulants and anti-cancer [34]. The main effect of saponins on bacteria is the release of proteins and enzymes in cells [35]. Saponins function as antimicrobials (antifouling) by inhibiting or killing microbes by interacting with sterol inhibitors [36];[37]. Saponins in sea cucumbers have been characterized as holothurin compounds [26]. Saponins have also been reported as toxic or bioactive compounds [38].

\section{Antifouling test of local sea cucumber (Phyllophorus sp.) methanol extract against Nerita sp.}

In order to determine the ability of local sea cucumber methanol extract (Phyllophorus sp.). In inhibiting the attachment of biofouling, a measurement parameter is needed that can represent the relationship, one of which is a parameter antifouling rate. Analysis antifouling rate used to determine the level of adherence (inhibition) of local sea cucumber methanol extract ( Phyllophorus sp.) against macrofouler Nerita sp. Before conducted antifouling test, it is necessary to check the condition of the maintenance water quality first first with purpose to ensure that the water quality is in accordance with the quality standards required by the biota Nerita sp. Test the water quality 3 repetitions for each parameter. The purpose of measuring water quality in this study is to control the conditions of water quality during maintenance. The measured water quality test includes temperature, salinity, DO and $\mathrm{pH}$. Measurement of water quality is used as supporting data to support it research this. Result from water quality measurement are presented in Table 2.

Table 2 Water Quality Measurement

\begin{tabular}{|l|c|c|l|}
\hline Parameter & Mean & $\begin{array}{c}\text { Optimum } \\
\text { Value }\end{array}$ & \multicolumn{1}{|c|}{ Source } \\
\hline Salinity & $31,2{ }^{0} \mathrm{C}$ & $28-32$ & $\begin{array}{l}\text { KEPMEN.LH } \\
\text { No.59 Year 2004 }\end{array}$ \\
\hline Temperature & $34 \mathrm{ppt}$ & $33-34$ & $\begin{array}{l}\text { KEPMEN.LH } \\
\text { No.59 Year 2004 }\end{array}$ \\
\hline $\mathrm{DO}$ & 7,6 & $7-8,5$ & $\begin{array}{l}\text { KEPMEN.LH } \\
\text { No.59 Year 2004 }\end{array}$ \\
\hline $\mathrm{Ph}$ & $3 \mathrm{mg} / \mathrm{ml}$ & $3-7$ & $\begin{array}{l}\text { Kadim, et al., } \\
2017\end{array}$ \\
\hline
\end{tabular}

Temperature is one of the parameters that plays an important role for the survival of marine life both in situ and exitu. Temperature affects the rate of metabolism of aquatic ecosystems. Measurement results temperature in research showing score amounting to $31.2{ }^{\circ} \mathrm{C}$. Based on [39] the optimal temperature value for marine biota ranges from $28-32{ }^{\circ} \mathrm{C}$.

Salinity the presence of adhering biota in the waters, this is because each organism has a different tolerance to salinity. The results of the salinity measurement in the study showed a result of $34 \mathrm{ppt}$. Based on [39], the optimal salinity value for biota ranges from 33-34 ppt. Tthe salinity for the growth of adhering biota ranges from $30-33$ ppt.

Based on the measurement results, the $\mathrm{pH}$ value in the study showed a value of 7.6. Based on [29], the 
optimal $\mathrm{pH}$ for marine life ranges from 7 - 8.5, which means that the $\mathrm{pH}$ value in the study is classified as optimal for the maintenance of adhering biota. The degree of acidity, also known as $\mathrm{pH}$, has a less significant direct effect on the attachment of biota fouling. This has been reported by [40] which states that a decrease in $\mathrm{pH}$ has a less significant direct effect on larval development and attachment of fouling biota.

Dissolved oxygen is one of the important parameters needed by biota for the respiration process and the breakdown of organic substances. The need for dissolved oxygen tends to vary depending on the type, stage and activity [41]. The results of measuring DO at the time of the study were obtained a value of $3 \mathrm{mg} / 1$. The optimal DO value for marine life ranges from $3-7 \mathrm{mg} / \mathrm{l}$ [42].

\section{Antifouling Rate}

So that knowing ability local sea cucumber methanol extract (Phyllophorus sp.) in hinder sticking biofouling, a measurement parameter that can represent the relationship is needed, one of which is the antifouling rate parameter. Analysis antifouling rate use to know level sticking (inhibition) local sea cucumber methanol extract (Phyllophorus sp.) against macrofouler Nerita sp. (Fig. 4).

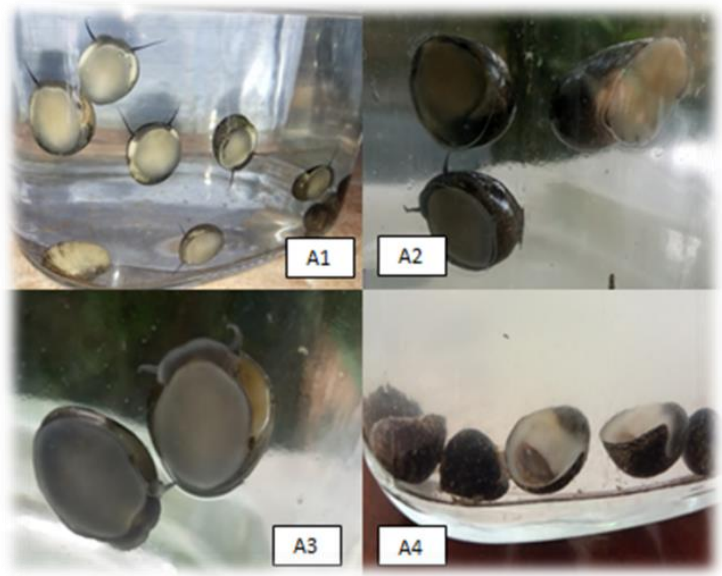

Fig. 4 Type of Treatment (A1) Treatment of negative control, (A2) Treatment of sea cucumber extract concentration of $75 \mathrm{mg} / \mathrm{ml}$, (A3) Treatment of sea cucumber extract concentration of $100 \mathrm{mg} / \mathrm{ml}$, (A4) Treatment of sea cucumber extract concentration of $200 \mathrm{mg} / \mathrm{ml}$.

The results of the local sea cucumber extract antifouling activity test (Phyllophorus sp.) on a laboratory scale in A1 treatment, namely negative control, it shows that all test biota is attached to the aquarium wall while the opposite occurs in treatment A5, namely positive control where almost all test biota does not stick to the aquarium wall. This happens because in the A5 treatment an antifouling paint is added so that the chemical compounds contained in the paint are exposed to water so that it affects the physiological conditions of the macrofouler. Nerita sp. which causes inhibition due to the antifouling compound of the paint.

Based on the results of the antifouling test, it shows that some biota is still attached Nerita sp (Fig. 4) on the aquarium. Condition Nerita sp. that is not attached is indicated by closing tightly operculum and is at the bottom of the aquarium (Fig. 5). In this research, when an active liquid stimulus such as methanol extract from local sea cucumber was exposed on the foot, Nerita sp. contracted its foot immediately.

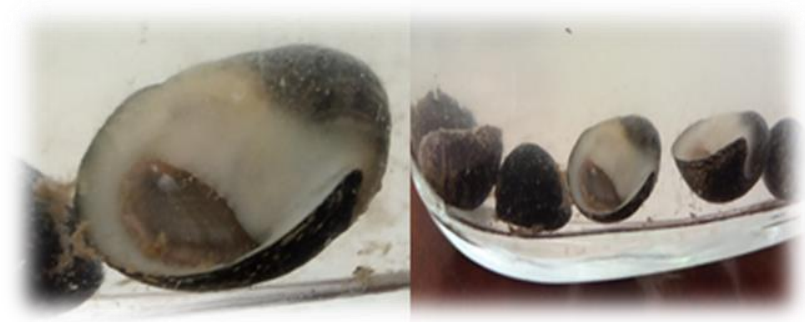

Fig. 5 The condition of Nerita sp. at the bottom of the aquarium

Percentage value of antifouling for 1 x 24 hour observation in A1 treatment (negative control), A2 treatment (concentration $75 \mathrm{mg} / \mathrm{ml}$ ), A3 treatment (100 $\mathrm{mg} / \mathrm{ml})$, A4 treatment $(200 \mathrm{mg} / \mathrm{ml})$ and A5 treatment (positive control) ) at $0 \%, 50 \%, 53.3 \%, 80 \%$ and $90 \%$, respectively. The percentage of antifouling for observation $2 \times 24$ hours in treatment A1 (negative control), treatment A2 (concentration $75 \mathrm{mg} / \mathrm{ml}$ ), treatment A3 (100 mg / $\mathrm{ml})$, treatment A4 $(200 \mathrm{mg} / \mathrm{ml})$ and treatment A5 (positive control) respectively $0 \%, 50 \%, 60 \%, 73 \%$ and $87 \%$ (Fig. 6)

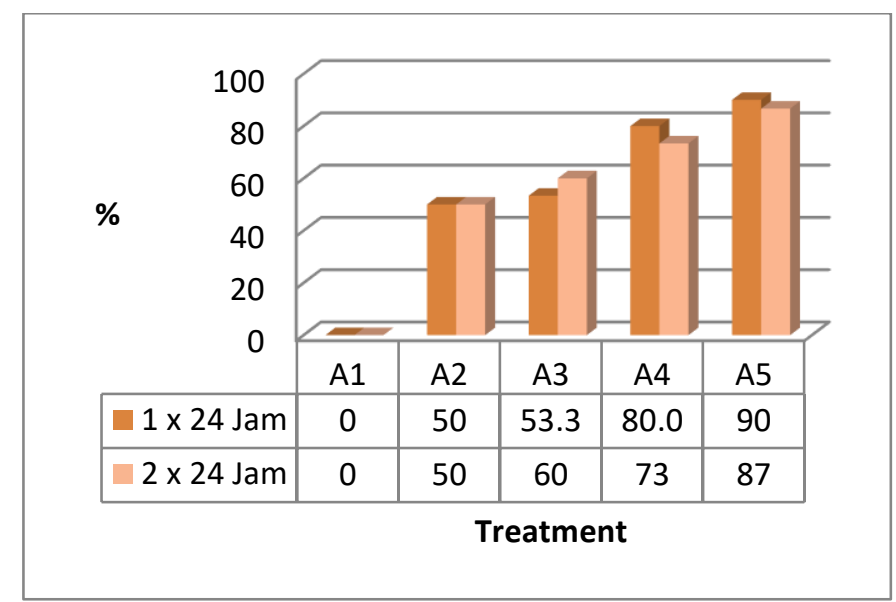

Fig. 6 Antifouling rate

It is known that the higher the extract concentration, the greater the antifouling rate value (Fig. 6). This is thought to be due to the fact that the higher the extract concentration, the higher the saponins, alkaloids, steroids, phenolics and tannins. Womb the have ability as an antifouling. This is in accordance with research from [43], in the study it was known that tannins could hinder growth biofouling even at low concentrations.

The results of this study indicate that Nerita sp. disturbed with addition of local sea cucumber methanol extract (Phyllophorus sp.). This is due to the local sea cucumber methanol extract (Phyllophorus sp.) contains secondary metabolite compounds which function as antifouling. Sea cucumbers contain many toxic compounds such as saponins (Holothurin). These toxic compounds can be used as a source of potent antifouling [44].

Alkaloid and phenolic compounds also reduce could total sticking biofouling because these two 
compounds are poisonous which can kill biofouling [30]. To knowing influence the concentration of local sea cucumber methanol extract (Phyllophorus sp.) to the antifouling rate it is necessary to test One Way ANOVA. Before the test One Way ANOVA is done so first it is necessary to test for normality and homogeneity.

\section{Regaining Rate}

Other factors besides the antifouling rate can be used to determine whether the local sea cucumber methanol extract (Phyllophorus sp.) can be used as an antifouling is the regaining rate. The test biota that has been tested for antifouling is then transferred to the aquarium for analysis regaining rate. Regaining rate analysis was performed to look ability recovery of the test biota after receiving treatment form addition extract local sea cucumber methanol (Phyllophorus sp.). (Table 3). The results of the regaining rate analysis show the results as in the following figure (Fig. 7).

Based on picture indicates that the value regaining rate in each different treatment. The regaining rate values for treatment $\mathrm{A} 1, \mathrm{~A} 2, \mathrm{~A} 3, \mathrm{~A} 4$ and $\mathrm{A} 5$ were $96.7 \%, 85 \%, 60 \%, 45 \%$ and $6.7 \%$, respectively.

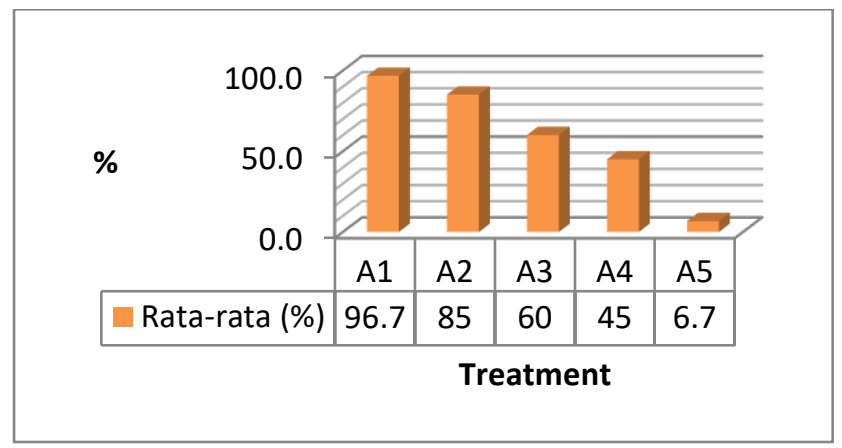

Fig. 7 Regaining rate

This value shows that the higher the concentration of local sea cucumber methanol extract (Phyllophorus sp.) is given then the value regaining rate the smaller it is, this is because the bioactive compounds in the extract exceed the tolerable limit Nerita sp so that it affects his recovery ability.

Tabel 3 Behavior of the test biota after being treated in fresh sea water

\begin{tabular}{|c|c|}
\hline Concentration & $\begin{array}{l}\text { Behavioural change of snails observed during } \\
\text { exposure and after in fresh sea water }\end{array}$ \\
\hline Control (-) & Open operculum and rapid movement \\
\hline $75 \mathrm{mg} / \mathrm{ml}$ & Moving with spread foot and regained immediately \\
\hline $100 \mathrm{mg} / \mathrm{ml}$ & Start moving within 10 minutes \\
\hline $200 \mathrm{mg} / \mathrm{ml}$ & $\begin{array}{l}\text { Start removing the foot within } 30 \text { minutes and part of } \\
\text { the test biota died }\end{array}$ \\
\hline Control $(+)$ & $\begin{array}{l}\text { Almost all of the test biota died, Nerita sp. floats on the } \\
\text { surface of the water with body part popping out of the } \\
\text { shell }\end{array}$ \\
\hline
\end{tabular}

Behavioural change of Nerita sp. observed during exposure and after in fresh sea water, it showed a different response in each treatment. Response Nerita sp. at a concentration of $75 \mathrm{mg} / \mathrm{ml}$ shows a response in the form of a snail starting to remove its antennae and walking quickly. Response Nerita sp. at a concentration of 100 $\mathrm{mg} / \mathrm{ml}$ is characterized by its onset movement after 10 minute put into sea water. A concentration of $200 \mathrm{mg} / \mathrm{ml}$ shows a response such as starting removing foot within 30 minutes, some of the test biota died. Provision of local sea cucumber methanol extract (Phyllophorus sp.) causes a reaction between the active substance and the receptors in the effector organ causing symptoms of poisoning. Each test biota used gives a different response at a certain concentration. The difference in response is due to differences in the sensitivity level of each biota (Fig. 8).

\section{Influence Antofouling Rate To Regaining Rate}

Based statistical test between concentrations local sea cucumber methanol extract (Phyllophorus sp.) against the antifouling rate macrofouler Nerita sp. It is known that the extract concentration has a significant effect on the antifouling rate macrofouler Nerita sp. The same thing happened to the results of the analysis between the extract concentration and the regaining rate, which also showed a significant influence between the extract concentration and the regaing rate. macrofouler Nerita $\mathrm{sp.}$

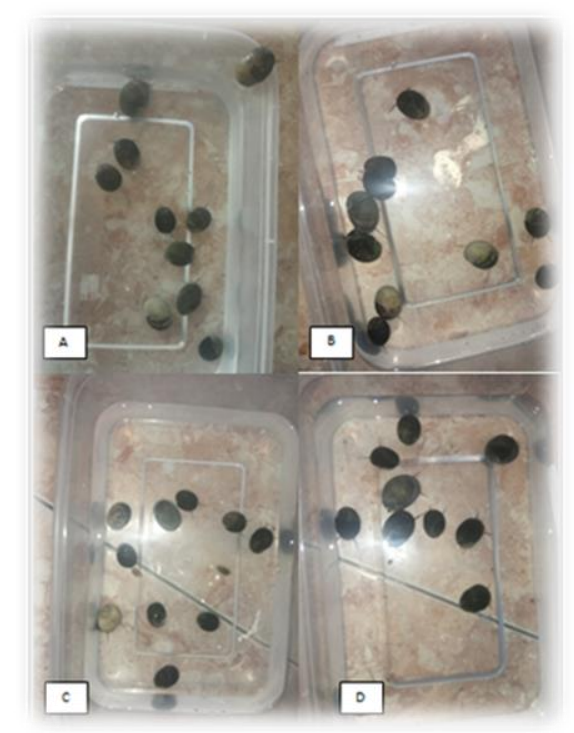

Fig. 8 (A) A1 treatment, (B) A2 treatment, (C) A3 treatment, (D) A4 treatment

Follows up on the above, giving rise to the question, whether the antifouling rate and regaining rate have a correlation with each other. To find out this, it is necessary to do further tests. One of the tests that can be done is a simple linear regression test. Simple linear regression analysis is used to determine whether the antifouling rate and regaining rate factors influence each other.

\section{Analysis Lethal Concentration $50\left(\mathrm{LC}_{50}\right)$}

Rate the percentage of deaths macrofouler Nerita sp. at each concentration showed different results. The largest percentage value of death occurred in treatment A5 which was $90 \%$, then followed by A4 treatment which was $50 \%$. The smallest percentage value of death in treatment A1 is $0 \%$. This mortality percentage value is then used to perform $\mathrm{LC}_{50}$ by using the probit method [45]. 
$\mathrm{LC}_{50}$ carried out with the aim of knowing the concentration that can cause death by $50 \%$ of the test organism which can be estimated using graphs and calculations on a observation certain. Lethal concentration 50 or $\mathrm{LC}_{50}$ is a calculation to determine the activity of an extract or compound. $\mathrm{LC}_{50} 48 \mathrm{H}$ can be determined using the test statistics (Fig. 9).

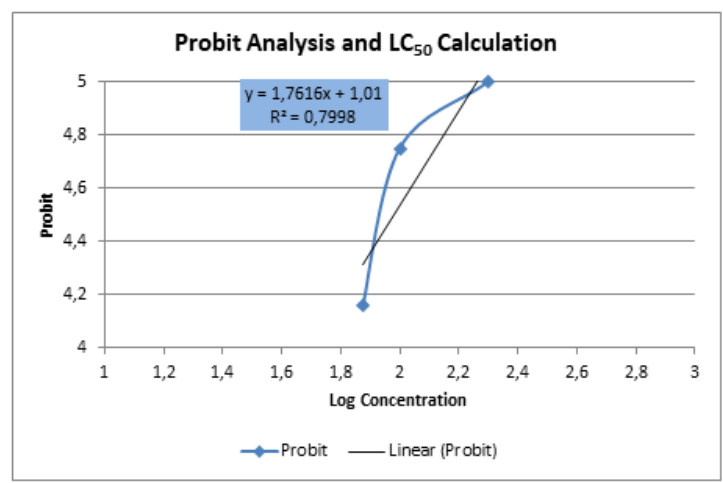

Fig. 9 Probit analysis and $\mathrm{LC}_{50}$ calculations

Based on the calculation results lethal concentration 50 or $\mathrm{LC}_{50}$ earned value amounting to 185.18. This means concentration sea cucumber extract (Phyllophorus sp.) is lethal in 50\% of all tested biota, namely at a concentration of $185.18 \mathrm{mg} / \mathrm{ml}$. Score lethal concentration 50 or $\mathrm{LC}_{50}$ amounted to 185.18 based on the low toxicity category [46].

Local sea cucumber methanol extract (Phyllophorus sp.) has the ability to kill fouling biota even in low concentrations. The total concentration of local sea

\section{CONCLUSIONS}

Local sea cucumber methanol extract (Phyllophorus sp.) have content of compounds such as saponins, alkaloids, tannins, steroids and phenolics. It give influence on the value of the antifouling rate by reducing the adhesion rate macrofouler Nerita sp. with increasingly increasing concentration. The same thing happened Where increasingly increase in extract concentration give drop significant on regaining ability macrofouler Nerita sp. It also has an impact on value nerita's macrofouler regaining rate $\mathrm{sp}$. where the smaller the concentration given, the regaining rate value macrofouler Nerita $\mathrm{sp}$. the greater it is. Variation concentration that applied to give a response different against macrofouler Nerita sp.

\section{REFERENCES}

[1] Baveridge, C.M.1987. Cage Aquaculture. Dorset Press. Porchester. 365 pp

[2] Rejeki, S. 2009.Suksesi Penempelan Makro Marine-biofouling Pada Jaring Karamba Apung di Teluk Hurun Lampung. Ilmu Kelautan. vol. 14 (2) : 112-117

[3] Syahputra, F., \& Almuqaramah, T. 2019. Penambahan ekstrak larutan kulit mangrove pada cat minyak sebagai antifouling. Aquatic Sciences Journal, 37-40.Tambaru, R. 2000. Pengaruh Waktu Inkubasi Terhadap Produktivitas Primer Di Perairan Teluk Hurun. (Thesis). Bogor. Program Pasca Sarjana; Insitut Pertanian Bogor cucumber methanol extract (Phyllophorus sp.) can also determine the inhibition of attachment of biota fouling and regaining rate his. Research result shows that the increasing the concentration, the more the inhibition of the sticking increases. The opposite happened if increasingly increasing concentration then the regaining value will decrease. Analysis results antifouling rate, regaining rate and lethal concentration $50\left(\mathrm{LC}_{50}\right)$ it can be concluded that the concentrations of $75 \mathrm{mg} / \mathrm{ml}, 100 \mathrm{mg} / \mathrm{ml}$ and 200 $\mathrm{mg} / \mathrm{ml}$ are effective in inhibits adhesion macrofouler Nerita sp. If a concentration of $100 \mathrm{mg} / \mathrm{ml}$ and $200 \mathrm{mg} /$ $\mathrm{ml}$ is applied in the field it will only cause waste of the extract, this is because at low concentrations only local sea cucumber methanol extract (Phyllophorus sp.) can inhibit the attachment of biota fouling.

Research on sea cucumber extract as antifouling has also been done by [44] showing that the extract of sea cucumber (H. Scabra) proven effective in inhibiting P. vulgata. Concentrations that are effective in inhibiting $\mathrm{P}$. vulgata is at a concentration of $4.2 \mathrm{mg} / \mathrm{ml}$. This concentration indicates a safe dose to use because regaining rate value more than $80 \%$ after testing. Extract H. Scabra is toxic at a concentration of $6.5 \mathrm{mg} / \mathrm{ml}$, this is indicated by almost all P. Vulgate die. Another study by Mokhase also showed that $H$. leucospilota methanol extract effective in inhibiting the growth of diatom biofilms among them Subinflated navicula and $N$. Crucicula. Antifouling compound content in $H$. Leucospilota methanol extract have been specifically identified.

While, the lethal concentration 50 or $\mathrm{LC}_{50}$ obtained a value of 185.18 . This means concentration extract sea cucumber (Phyllophorus sp.) is lethal in $50 \%$ of all tested biota, namely at a concentration of $185.18 \mathrm{mg} / \mathrm{ml}$. So, It is known that the most effective concentration that can be used as an antifouling agent is $75 \mathrm{mg} / \mathrm{ml}$. This is because at a concentration of $75 \mathrm{mg} / \mathrm{ml}$ of local sea cucumber methanol extract (Phyllophorus sp.) can already inhibit sticking macrofouler Nerita sp. a concentration of $75 \mathrm{mg} / \mathrm{ml}$ also has value regaining rate which is also big, namely by $85 \%$.

[4] Basri, N.B, Syawal N.H, \& Baharuddin N. 2018. Marine gastropods (Gastropoda; Mollusca) diversity and distribution on intertidal rocky shores of Terengganu, Peninsular Malaysia. AACL Bioflux , 1144-1154

[5] Eichhorst, T. 2016. Neritidae Of The World. Conchbooks, 694 pp.

[6] Armstrong, E., Boyd, K.G. \& Burgess, J.G. 2000. Prevention of marine biofouling using natural compounds from marine organisms, Biotechnology Annual Review. Elsevier, pp. 221-241

[7] Marhaeni, B. 2008. Biofouling Pada Beberapa Jenis Substrat Permukaan Kasar dan Halus. Sains Akuatik. 
[8] La Didu, Ma'ruf K., \& Emiyarti. 2019. Komposisi Jenis dan Kepadatan Makrobiofouling Pada Jaring Kantung Apung Dengan dan Tanpa Menggunakan Sintetik Anti Fouling Hubungannya dengan Pertumbuhan Kappapycus alvarezii Di Perairan Pantai Lakeba Kota Baubau . Jurnal Manajemen Sumber Daya Perairan, 111-121

[9] Huang, C.C. 2000. Engineering Risk Analyses for Sub-merged Cage Net System in Taiwan. In Cage Cul-ture in Asia: Proceeding for the First International Symposium on Cage Aquaculture in Asia (ed. IC. Liao and C.K. Lin), 133-40 pp

[10] Phillipi, A.L., N.J. O’Connor, A.F. Lewis, \& Y.K. Kim, 2001. Surface Flocking as a Possible Antibiofou-lant. Aquaculture 195: 225 - 238Pranoto, E., W.F

[11] Tan, C.K.F., B.F., Nowak, \& S.L.Hodson, 2002. Biofoul-ing as Reservoir of Neoparamoeba pemaquiden-sis, the Causive Agent of Amoebic Gill Disease in Atlantic Salmon. Aquaculture 210: 49-58

[12] Swift, M.R., D.W..Fredericson, A. Unrein, B. Fullerton, O. Patursson, \& K. Baldwin, 2006. Drag Force Act-ing on Biofouled Net panels. Aquaculture Engi-neering 35: 292-299

[13] Railkin, A. 2004. Marine biofouling: Colonization processes and defenses. Boca Raton, FL, USA: CSC Press.

[14] PEREIRA, R.C., M. D. PINHEIRO and B.A.P. DA GAM A .2002. Feeding preference of the endemic gastropod Astraea latispina in relation to chemical defenses of Brazilian tropical seaweeds. Braz. J. Biol., 62 : 33-40

[15] Boesono, H. 2008. Pengaruh Lama Perendaman Terhadap Organisme Penempel dan Modulus Elastisitas Pada Kayu. Ilmu Kelautan. Vol 13(3) : $177-180$

[16] Bhadhury, P., \& Wright, P. 2004. Exploitation of Marine Algae: Biogenic Compounds for Potential Antifouling Applications. Planta, 561-578.

[17] Pérez, M., et al. 2009. Advances in Marine Antifouling Coatings and Technologies. Woodhead Publishing Ltd \& CRC Press LLC, Cambridge, UK

[18] Amin, M. 2017. Uji Ekstrak Daun Ketapang (Terminalia catappa) Sebagai Bahan Antifouling Alami Pada Plat Baja Di Perairan PT DOK Dan Perkapalan Surabaya. Surabaya: Institut Teknologi Sepuluh November.

[19] Bordbar, S., Farooq A., dan Nazamid S. 2011. High-Value Components and Bioactives from Sea Cucumbers for Functional Foods ${ }^{2} \mathrm{~A}$ Review [Marine Drugs Journal]. 1761-1805 hlm

[20] Nimah, S., Widodo F.M, \& Agus T. 2012. Uji Bioaktifitas Ekstrak Teripang Pasir (Holothuria scabra) Terhadap Bakteri Pseudomonas aeruginosa Dan Bacillus cereus. Jurnal Perikanan, 1.

[21] Farouk, A. E. A., Ghouse, F. A. H. \& Ridzwan, B. H. 2007. New Bacterial Species Isolated from Malaysian Sea Cucumbers with Optimized Secreted Antibacterial Activity, American Journal of Biochemistry and Biotechnology 3 (2), 60-65

[22] Dwicahyani, T., Rianingsih , L., \& Sumardianto. 2018. Uji Bioaktivitas Ekstrak Teripang Keling (Holothuria atra) Sebagai Antibakteri
Staphylococcus aureus dan Escherichia coli. Jurnal Pengolahan dan Bioteknologi Hasil Perikanan, 7.

[23] Harborne, J. B. 1987. Metode Fitokimia: Penuntun Cara Modern MenganalisisTumbuhan. Terbitan Kedua, diterjemahkan oleh Padmawinata, K. \& Sudiro, I. ITB Press, Bandung

[24] Lubis, M., \& Pujiyati, S. 2013. Pengaruh Aklimatisasi Kadar Garam Terhadap Nilai Kematian Dan Tingkah Laku Ikan Gupy (Poecilia reculata) Sebagai Pengganti Umpan Ikan Cakalang (Katsuwonus pelamis). Jurnal Teknologi Perikanan dan Kelautan, 123-129

[25] Sastrosupadi, A. 2000. Rancangan Percobaan Praktis. Kanisus.Yogyakarta.276 hal

[26] Arlyza, I. 2007. Bahan Aktif Dari Organisme Laut Sebagai Pengendali Biota Penempel. Jurnal Oseana, 32.

[27] Masduki I, 1996. Efek Antibakteri Ekstrak Biji Pinang (Areca catechu) terhadap S. aureus dan E. coli. Cermin Dunia Kedokteran 109. pp. 4-21

[28] Ajizah, Aulia. 2004. Sensitivitas Salmonella typhimurium terhadap ekstrak daun Psidium guajawa. Biosientiae Vol. 01: 31-38

[29] Damayanti, E. dan T. B. Suparjana. 2007. Efek penghambatan beberapa fraksi ekstrak buah mengkudu terhadap Shigella dysenteriae. Prosiding Seminar Nasional Tehnik Kimia Kejuangan. Fakultas Biologi Universitas Jenderal Soedirman. Yogyakarta

[30] Cowan, M. 1999. Plant product as antimicrobial agents. Clinical Microbiology Reviews, 564 - 582

[31] Bontjura S. 2015. Uji efek antibakteri ekstrak daun leilem (Clerodendrum minahassae 1.) terhadap bakteri streptococcus mutans. Jurnal ilmiah Farmasi- Pharmacon.; 4 (4):96-101

[32] Ahmed, Bahar. 2007. Chemistry Of Natural Products. New Delhi: Department of Pharmaceutical Chemistry Faculty of Science Jamia Hamdard.

[33] Muchtadi, T.R. 1989. Teknologi Proses Pengolahan Pangan. Departemen Pendidikan dan Kebudayaan Direktorat Jenderal Pendidikan Tinggi Pusat Antar Universitas Pangan dan Gizi Institut Pertanian Bogor. Bogor.

[34] Zhang, Y. S.; Yi, H. Y.; and Tang, H. F., 2006. Cytotoxsic Sulfated Triterpene Glycosides from The Sea Cucumber Pseudocolochirus Violaceus, Chemistry \& Biodiversity, 3:807-817

[35] Ma'ruf, \& D. Pringgenies . 2012. Kajian Aktivitas Bioaktif Ekstrak Teripang Pasir (Holothuria scabra) Terhadap Jamur Candida albicans. Jurnal Pengolahan dan Bioteknologi Hasil Perikanan, 1-8.

[36] Hardiningtyas, S.D. 2009. Aktivitas Antibakteri Ekstrak Karang Lunak Sarcophyton sp. yang Difragmentasi dan Tidak Difragmentasi di Perairan Pulau Pramuka, Kepulauan Seribu. [Skripsi]. Institut Pertanian Bogor, Bogor, $67 \mathrm{hlm}$

[37] Santi, I.W., O.K. Radjasa, dan I. Widowati. 2014. Potensi Rumput Laut Sargassum duplicatum Sebagai Sumber Senyawa Antifouling. Journal of Marine Research Vol. 3, No. 3: 274-284 
[38] Selvin J., \& A.P Lipton. 2002. Development Of a Rapid "Mollusk Foot Adherence Bioassay" For Detecting Potent Antifouling Bioactive Compounds. Current science, 735-737.

[39] KEPMEN LH No.59. 2004. Baku Mutu Bagi Biota Laut. Jakarta

[40] Baragi. L.V., Anil. A.C. 2017. Influence of Elevated Temperature,pCO2, and nutriens on larvabiofilm interaction: Elucidation with acorn barnacle, Balanus amphitrite Darwin(Cirripedia: Thoracica). Estuarine, Coastal and Shelf Science

[41] Gemilang, W.A., Rahmawan, G.A., Wisha, U.J., 2017. Kualitas Perairan Teluk Ambon Dalam Berdasarkan Parameter Fisika dan Kimia pada Musim Peralihan I. EnviroScienteae 13(1) : 79-90
[42] Kadim, M. K., Pasisingi, N., \& Paramata, A. R. 2017. Kajian kualitas perairan Teluk Gorontalo dengan menggunakan metode STORET. DEPIK Jurnal Ilmu-Ilmu Perairan, Pesisir dan Perikanan, 6(3), 235-241

[43] Idora, M. S., Ferry, M., Wan Nik, W., Jasnizat, S. 2015. Evaluation of tannin from Rhizophora apiculata as natural antifouling agents in epoxy paint for marine application. Progress in Organic Coating 81: 125-131

[44] Selvin, J and Lipton, A.P. 2004. Antifouling activity of bioactive substances extracted from Holothuria scabra. Hydrobiologia 513, hh. 251-253

[45] US EPA. 2002. Methods for Masuring The Acute Toxicity of Effluents and Receiving Waters to Freshwater and Marine Organism. Unites State: Environmental Protection Agency.

[46] Wagner, J.G. 1993. Pharmacokinetics For The Pharmaceutical Scientist. Techonomic Pub. Lancarter-Basel 